\title{
TYPIFICATION OF SENECIO CARPATHICUS (ASTERACEAE)
}

\author{
ZBIGNIEW SZELĄG \& YURIY KobiV
}

\begin{abstract}
Zbigniew Szelag, Pedagogical University of Cracow, Department of Botany, Podchorążych 2, 30-084 Kraków, Poland; e-mail: azszelag@wp.pl

Yuriy Kobiv, Institute of Ecology of the Carpathians, National Academy of Sciences of Ukraine, Kozelnytska Str. 4, 79026 Lviv, Ukraine; e-mail: ykobiv@gmail.com
\end{abstract}

Senecio carpathicus Herbich was described from specimens collected by Franz Herbich at Morskie Oko Lake in the Tatras, Western Carpathians, southern Poland (Herbich 1831). Senecio carpathicus is an Carpathian-Balkan endemic and occurs in the highest massifs of the Carpathians (Poland, Romania, Slovakia, Ukraine) and the Balkan Peninsula (Albania, Bosnia and Herzegovina, Bulgaria, Greece, Macedonia, Montenegro, Serbia) (Jäger 1992: distribution map).

Herbich (1791-1865), a botanist and military medical doctor (for more details of Herbich's activity see Köhler 2015) visited the Tatra Mts in 1829 and 1830 (Herbich 1834). During his second trip to the Tatras he explored the Morskie Oko glacial cirque, where he found S. carpathicus (Herbich 1834: 562).

Continuing the revision of Herbich's collection (Szeląg \& Kobiv 2014) in the herbarium of the Ivan Franko National University of Lviv (LW), we discovered three specimens collected by Herbich in the Tatras in 1830. One of them (LW 128057) comes from Morskie Oko lake mentioned in the protologue. Here we designate this specimen as the lectotype of the name $S$. carpathicus (Fig. 1).

Two other specimens from the Tatras (LW 128053,128058 ) were collected by Herbich from localities not enumerated in the protologue.

\section{Senecio carpathicus Herbich}

Fig. 1

Addit. ad Fl. Galic.: 43. 1831. - S. abrotanifolius var. carpaticus (Herbich) Rehmann, Verh. Zool-Bot. Ges.
Wien 18: 491. 1868. - S. abrotanifolius subsp. carpathicus (Herbich) Nyman, Consp. Fl. Eur.: 356. 1879. - Jacobea abrotanifolia subsp. carpathica (Herbich) B. Nord. \& Greuter, Willdenowia 36: 711. 2006. - Herbichia abrotanifolia Zawdzki, Flora 15: 630. 1832, nom. illeg. (Art. 52.1). - TYPE LOCALITY: 'In alpinis supra lacum Morskie Oko an nives'. - LeCTOTYPE (designated here): [Poland] in Carpatis principalibus (Tatra) circuli Sandeciensis ad lacum Morskie Oko [...], Julio 1830, F. Herbich (LW 128057).

- 'Senecio abrotanifolius L.' sensu Wahlenb., Fl. Carpat. Princip.: 266. 1814, non L. Spec. Plant.: 869. 1753.

OTHER HISTORICAL MATERIAL: [Slovakia] infra Lomnizer Spitze, August 1830, F. Herbich (LW 128053); [Slovakia] in Carpatis principalibus Tatra, alpibus Scepusiensibus die Hintere Leiten, August 1830, F. Herbich (LW 128058).

ACKNowledgements. We are grateful to Alexander N. Sennikov (Helsinki) for valuable comments and helpful suggestions on the manuscript, Tetiana Khmil (Curator of LW) for making the relevant collections available for study and providing excellent photographs of Herbich's specimens, and Wojciech Paul (Kraków) and Günter Gottschlich (Tübingen) for help with reading of the herbarium labels.

\section{REFERNCES}

Herbich F. 1831. Additamentum ad floram Galiciae. Kuhn et Millikowski, Leopoli, Stanislavoviae et Tarnoviae et C. Wenzel, Przemysliae.

Herbich F. 1834. Botanischer Ausflug in die galizisch-karpatischen Alpen des Sandezer Kreises. Flora 17: 561-575. 


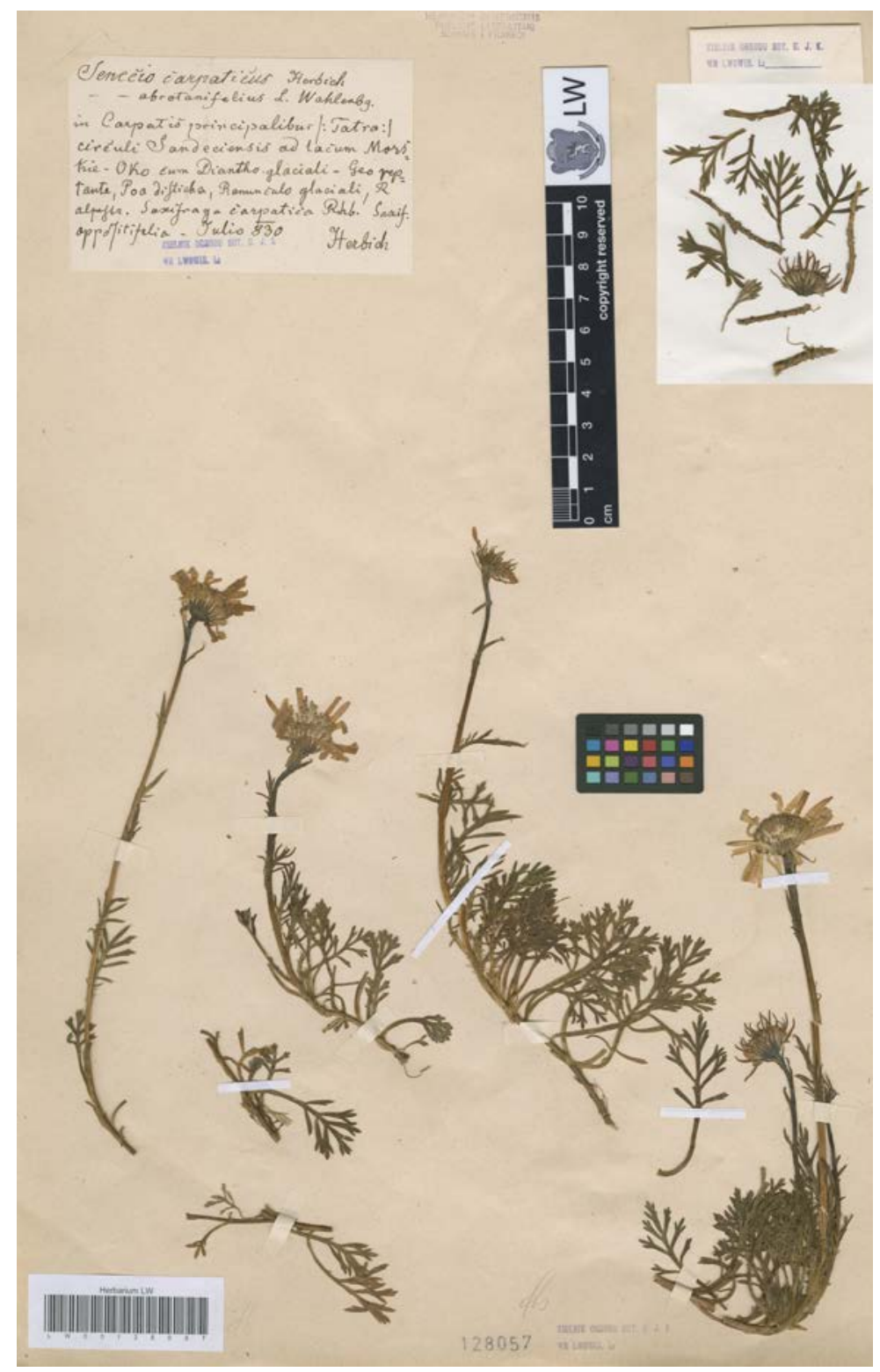

Fig. 1. Lectotype of Senecio carpathicus Herbich (LW 128057).

JÄGER E. J. 1992. Senecio abrotanifolius L. In: H. MeuSEL \& E. J. JÄGER (eds), Vergleichende Chorologie der zentraleuropäischen Flora. 3: 277. Gustav Fischer, Jena.

KöHLER P. 2015. The role of Franz Herbich (1791-1865) in the organization of research on the natural history of
Galicia (Austro-Hungarian Empire). Arch. Nat. Hist. 42(2): 308-313.

Szeląg Z. \& KoBIV Y. 2014. Typification of Chrysanthemum zawadzkii (Asteraceae). Polish Bot. J. 59: 27-30. 